\section{ENVIRONMENT AND GEOGRAPHY}

\subsection{The river and associated watercourses}

The River Dee forms the focus of the past human activity investigated during this fieldwork and will thus be described first. The river runs eastwards for approximately $140 \mathrm{~km}$ from its headwaters at the Wells of Dee in the Cairngorm massif, to the sea at the city of Aberdeen (Illus 4.1). Along its length, it drops from just over 1,200m OD and provides evidence for many classic riverine features, including terracing, braiding, waterfalls and pools. The bedrock underlying the glacial and other recent sediments throughout the river catchment comprises a variety of Precambrian granitic and metamorphic rocks (Illus 4.2). In places along the river this is exposed at the surface where it often gives rise to gorges, falls and rapids, such as at the Linn of Dee and Jock Young's Leap, Potarch. The river is classified by Scottish Natural Heritage as an 'alternately wandering gravel-bed and stable (confined) river' (Werrity \& Hoey 2004), meaning that while stretches of the river flow over an easily eroded gravel bed, allowing the river channel to wander, some reaches of the river are confined by bedrock and are thus more stable, leading to gorgelike reaches. McEwen (2001) found that around one-third of the wandering gravel-bed reaches are undergoing erosion while approximately half are subject to sediment deposition along point bars.

Though similar processes to those of today pertained along the length of the river in the past (McEwen 2001), the nature of the river was very different when the first human groups navigated it at the end of the last glacial. The River Dee is carefully managed and past and present activities such as salmon fishing, forestry and conservation have all played their part in the shape of the river today. This, of course, has implications for both the interpretation of past lifestyles and the preservation of archaeological material. The dynamic history

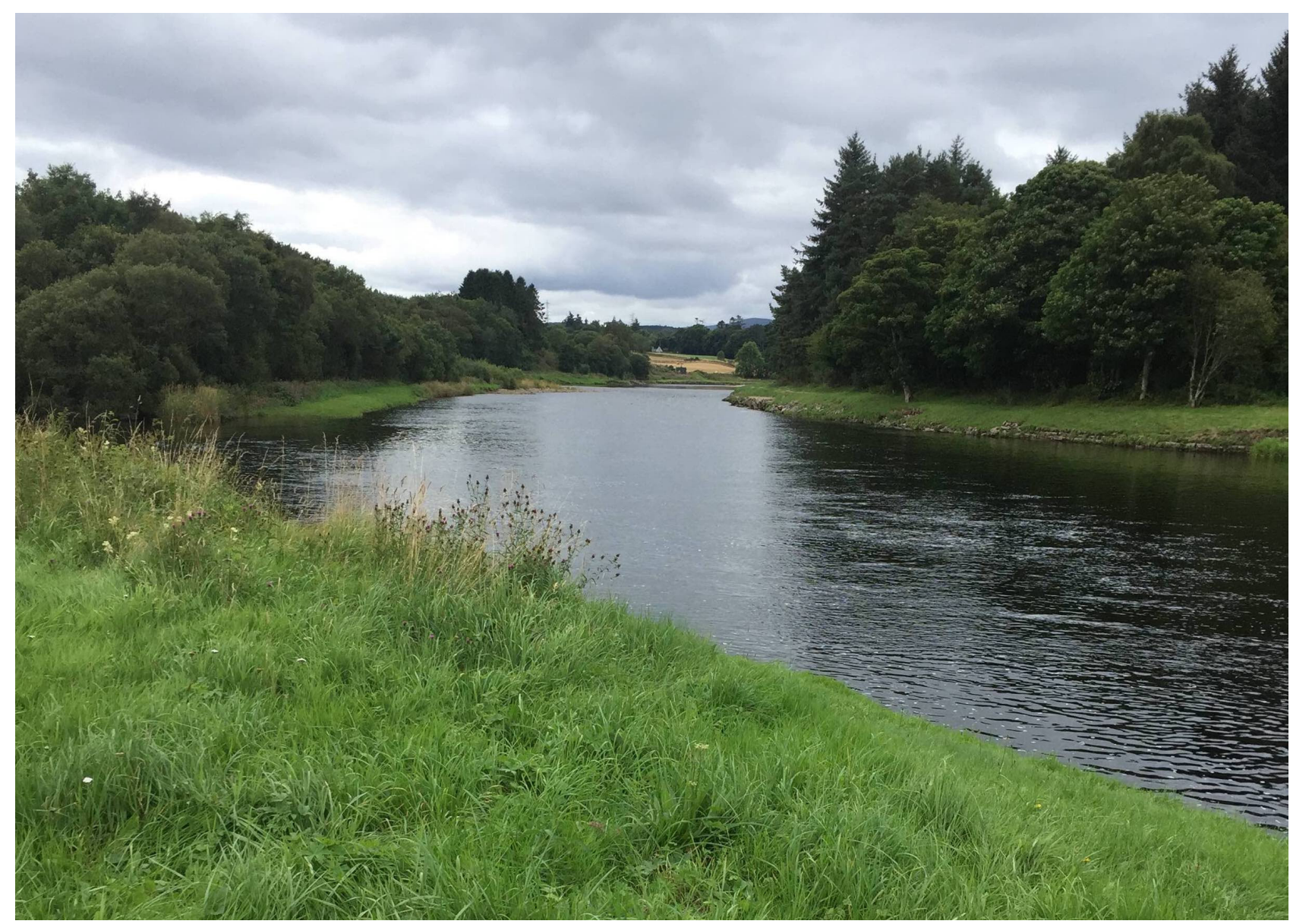

Illus 4.1 The River Dee. This aspect of the river, with its managed banks and planted riparian trees, belies the look of the watercourse in prehistory 


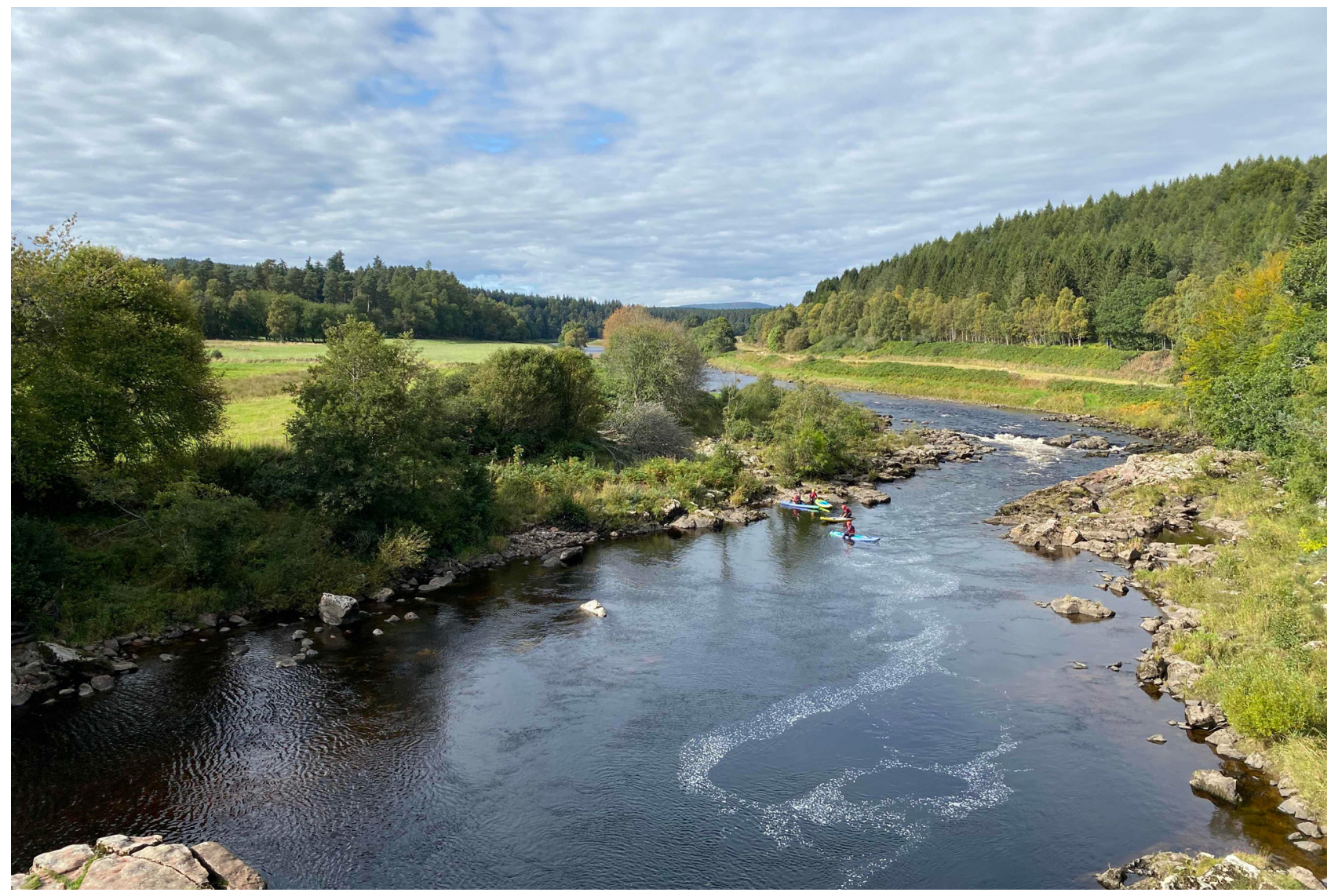

Illus 4.2 Outcropping bedrock constrains the River Dee at Jock Young's Leap, Potarch, to the west of Banchory

of the system is well illustrated by the landforms along its length and indicates the impact of both long-term and episodic events (McEwen 2001). While the course of the river is dictated by the antecedent of following the glacial valley, this, in turn, follows previous glaciations and river flow during interglacial cycles. So, the course and its pattern are the result of cycles over many glacial episodes. In general, rivers like the Dee have been incising downwards through their beds since the end of the last glaciation, due in part to the relative rising landmass of northern Britain, though the nature of the river is also impacted by other factors such as past climate change. Flooding, which can be very destructive for both the river channel and the local community, has occurred throughout its history (Illus 4.3; Macklin et al 2010; Fieman et al 2020). Abandoned palaeochannels evidence the way in which once braided stretches have been cut through as the river incised down to form a more stable (and usually narrower) course through the underlying bedrock or sediments. At Heughhead to the west of Aboyne, a classic series of palaeochannels may be seen on the terraces above the present river surface (Maizels \& Aitken 1991) and palaeochannels are a common feature of many of the surfaces walked in the present survey.

As experienced today, the River Dee is carefully managed. McEwen (2001: 12) notes the impact of the agricultural improvements on adjacent farmlands from the late 17 th century onwards, as well as of the transport of logs downstream from the upland forests in the 18th and 19th centuries, which required both the straightening of some lengths and the removal of certain bedrock impediments as at Potarch. These changes have a significant bearing on both travel and resource acquisition along the river. While the experience(s) of those who lived and travelled here in early prehistory was very different to those of the local community in the 21 st century, the significance of the river as a source of wild resources such as salmon and freshwater mussels, not to mention the flora and fauna of the riverbanks, is likely to have 


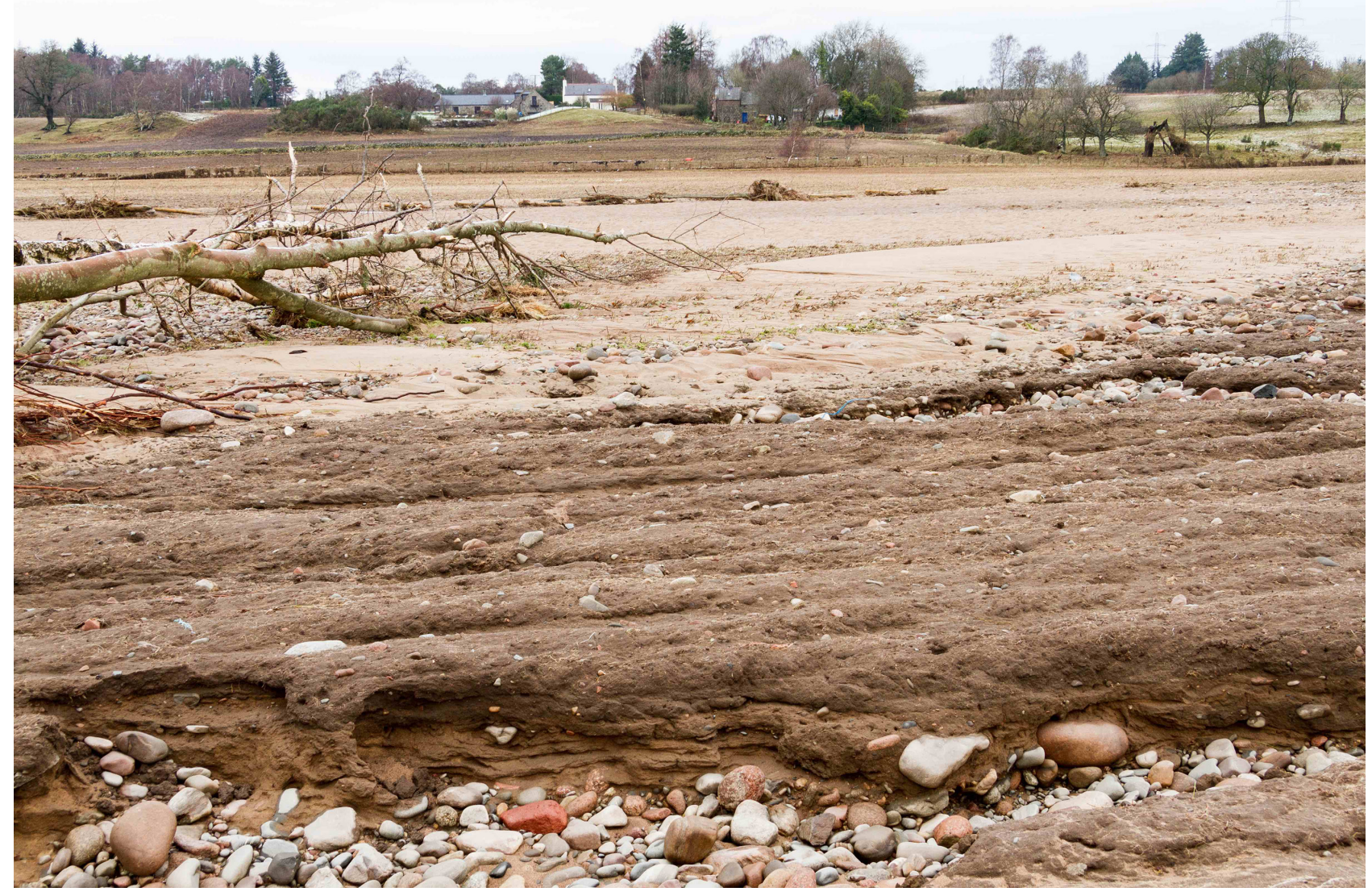

Illus 4.3 Damage caused in 2015 by Storm Frank, looking north across field NM5 to the houses at Mills of Drum. Note the fallen tree, veneer of fresh sand and eroded plough furrows

been high at all times (Dingwall et al 2019b: 32-7). The Dee today is celebrated as a 'perfect' fishing river: the snowy Cairngorm massif maintains a good water flow well into the early summer, the fall of the river (just over $2 \mathrm{~m}$ per kilometre on average) is mitigated by a succession of pools and rapids, and for most of the length the banks facilitate easy access to the water.

In addition to the changes in the river itself, the immediate landscape differs markedly from that of the Late Glacial and Early Holocene in many ways (Table 4.1), one of the most notable being the current absence of pronounced surface water features. Lochs and associated fen areas, as well as free-flowing burns, would have been much more common prior to recent centuries when agricultural improvements included large-scale drainage projects. These resulted in the disappearance of local lochs such as the Loch of Park and Loch of Leys (both illustrated on Timothy Pont's map of the area in the late 16th century, National Library of Scotland Adv. MS.70.2.9 (Pont 11); Bremner 1935). This is not just a matter of natural drainage; the contribution of animals, such as local beaver populations, to the alteration of a watery landscape should not be forgotten.

The Loch of Park, the most extensive of these lochs, to the north-west of Drumoak (Illus 4.4), comprised a moraine-dammed lake, the basal organic sediments of which have been dated by radiocarbon assay to $12,620-11,340$ вс (Vasari 1977; Tipping 2007). Deglaciation in the area is widely accepted to have been complete by c 12,750 BC (Ballantyne 2010) at, or shortly before, the arrival of human groups (as evidenced by Late Upper Palaeolithic stone tool assemblages from Milltimber: Ballin in Dingwall et al 2019b: 89-122; Nethermills: Wickham-Jones et al 2017; and East Park: see 7.2.2 'Lithics'). The existence of bodies of water such as these has considerable implications for local hunter-gatherer populations. They would have provided significant foci for acquiring resources as well as constraining movement around and across the region. 

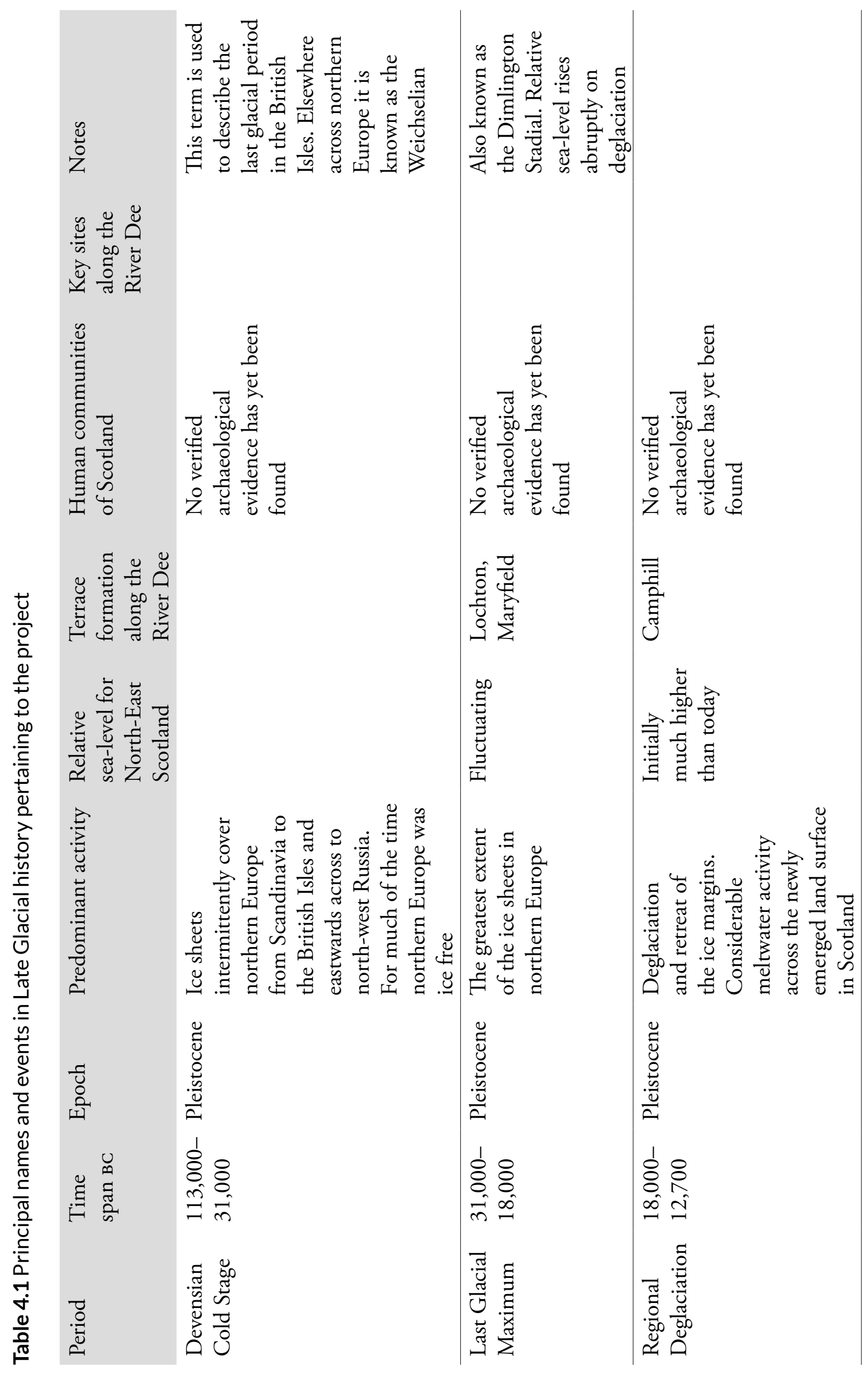

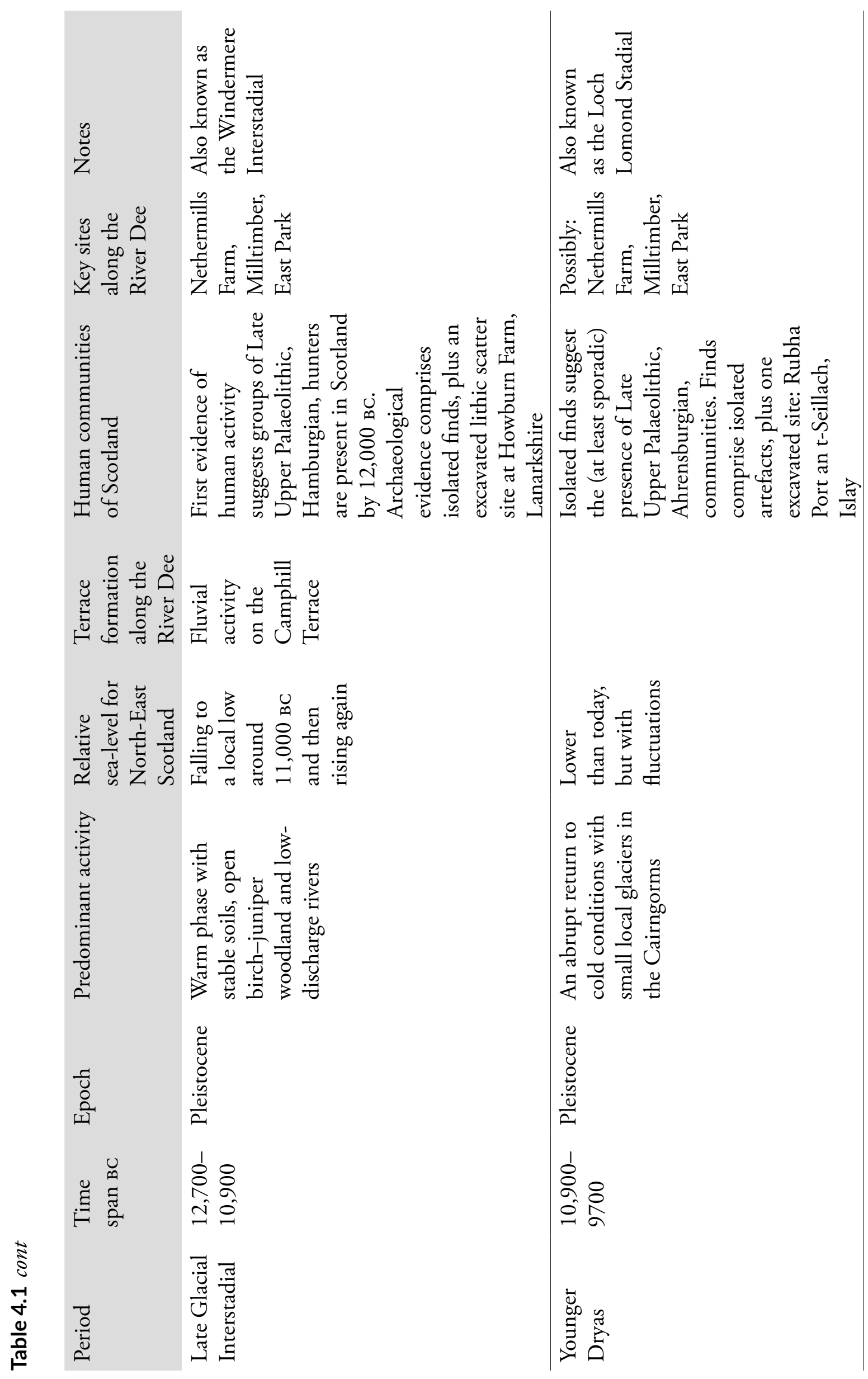


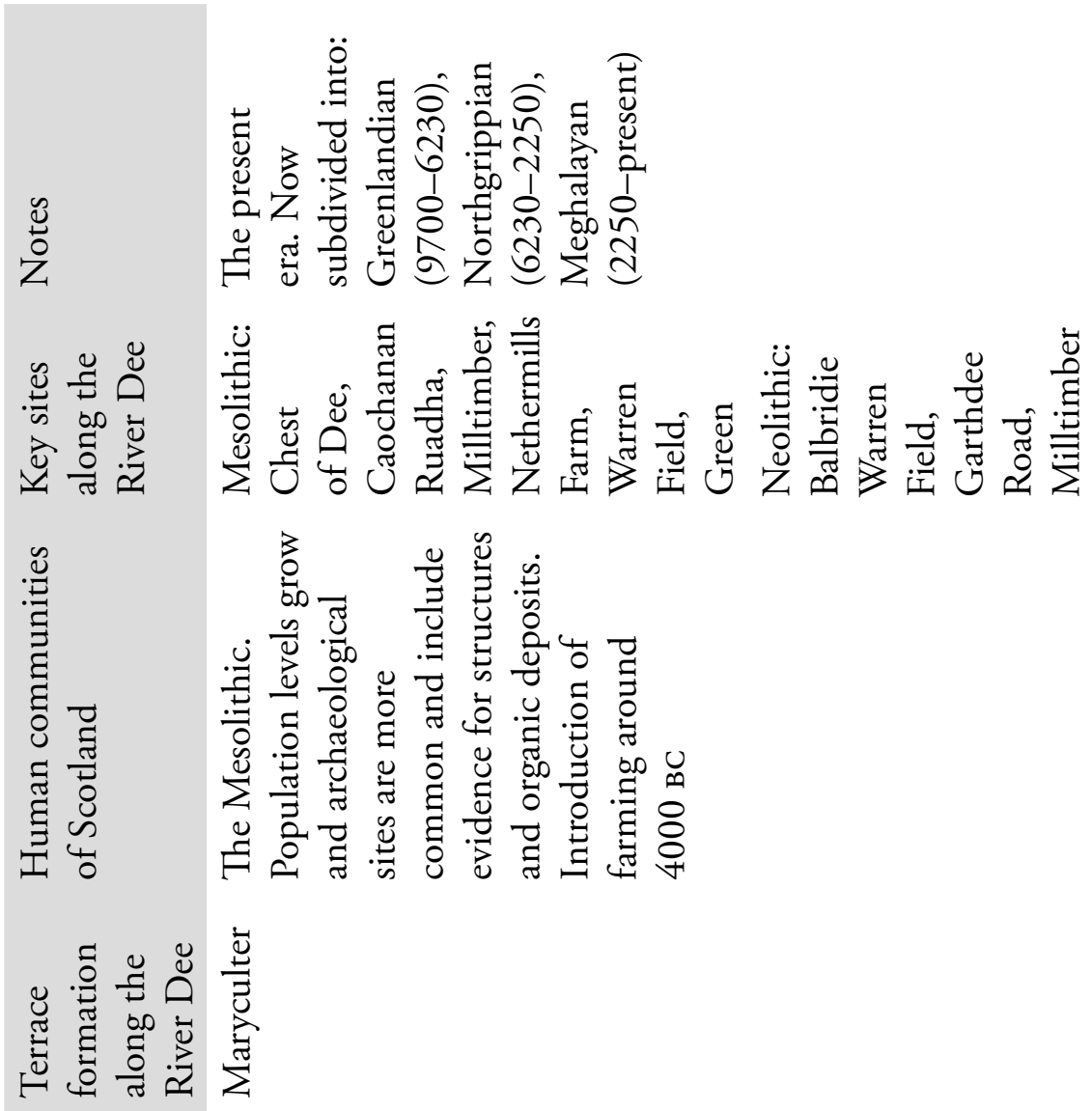

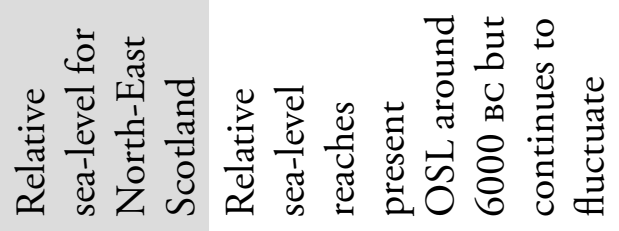

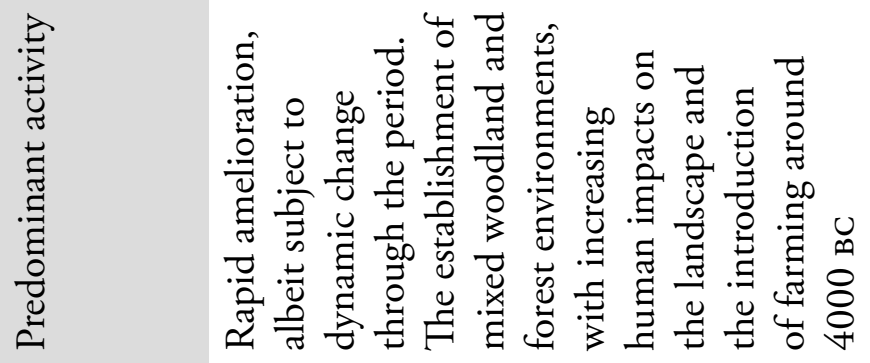

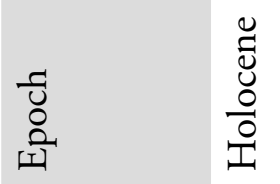

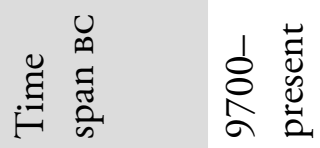

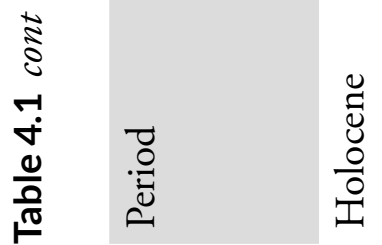




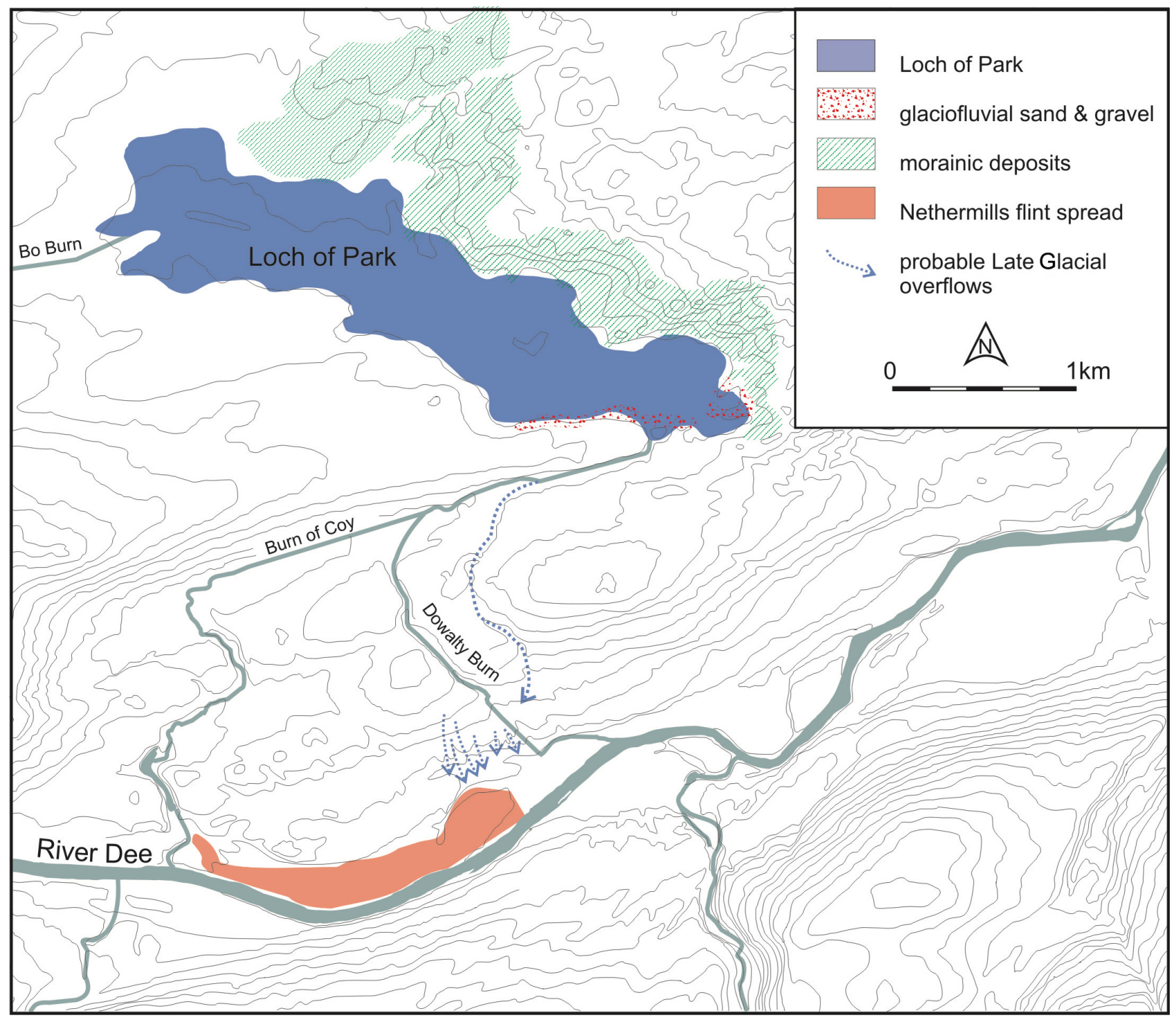

Illus 4.4 Reconstruction of the location of the Loch of Park. Information supplied by Michael Stratigos (pers comm) and Tipping et al (2009: illus 1). Note: the lithic spread at Nethermills Farm is illustrated in order to help orientation in the landscape; it should be noted that the loch formed millennia before the Mesolithic activity in the area, and was in existence well into the historic period

\subsection{The terraces of the Dee}

Richard Tipping \& Irvine Ross

The river terraces of the Dee are a significant factor in the shape of the land along the length of the river (McEwen 2001) and, where possible, the archaeological sites have been mapped in relation to specific surfaces. LiDAR data (https:// remotesensingdata.gov.scot/data\#/map) can be used to define four principal terrace surfaces and one more localised terrace, at different heights above the present surface of the river (Table 4.2) along the Banchory to Dalmaik stretch (Illus 4.5).
Each is comprised of gravels and sands, or of sand alone. While each terrace surface is assumed to be broadly synchronous along the length of the river, this has yet to be ascertained. All four surfaces fall downstream parallel to the present river surface at a gradient of around $2 \mathrm{~m}$ per kilometre.

These terraces were formed during the processes of deglaciation and subsequent periods, when extensive fluvial activity shaped the land. The youngest, the Maryculter Terrace, is still forming. Deglaciation in the area is still poorly understood but, as noted previously, most agree that it had been achieved by 12,750 вС (Tipping in Dingwall 
Table 4.2 The four principal terrace structures along the Banchory to Dalmaik stretch of the River Dee. Dating is described in more detail below

\begin{tabular}{|c|c|c|c|c|}
\hline Terrace & $\begin{array}{l}\text { BGS nomenclature } \\
\text { (Merritt et al 2003) }\end{array}$ & $\begin{array}{l}\text { Height above the } \\
\text { present surface of } \\
\text { the Dee }(\mathrm{m})\end{array}$ & Composition & Dating controls \\
\hline Lochton & $\begin{array}{l}\text { Lochton Sand and } \\
\text { Gravel Formation }\end{array}$ & $15.5-17.0$ & Gravel & $\begin{array}{l}c 14,500 \text { вс (Hall et al } \\
2016)\end{array}$ \\
\hline Maryfield & $\begin{array}{l}\text { Lochton Sand and } \\
\text { Gravel Formation }\end{array}$ & $9.5-11.0$ & Gravel & $\begin{array}{l}\text { Late Upper Palaeolithic } \\
\text { lithics: older than } \\
\text { c } 13,000 \text { вС }\end{array}$ \\
\hline Camphill & $\begin{array}{l}\text { River terrace deposits } \\
\text { (undifferentiated) } \\
\text { gravel, sand and silt }\end{array}$ & $4-5$ & $\begin{array}{l}\text { Sand over } \\
\text { gravel }\end{array}$ & $\begin{array}{l}\text { Late Upper Palaeolithic } \\
\text { lithics: >c } 13,000 \text { BC } \\
\text { Palynological dating (see } \\
4.2 \text { 'The terraces of the } \\
\text { Dee') suggests terrace } \\
\text { formation ceased by } \\
\text { c } 9700 \text { вс }\end{array}$ \\
\hline Maryculter & Alluvium & $2-3$ & Sand & $>c 2500$ вС \\
\hline
\end{tabular}

et al 2019b: 22-33). The most significant legacy of deglaciation is coarse boulder-rich gravel lining the Dee, tens of metres thick, called the Lochton Sand and Gravel Formation (Merritt et al 2003), laid down by meltwater. The Lochton and Maryfield Terraces represent earlier iterations of the valley floor, across which many active river channels were able to wander. These terraces formed as the river cut down in response to the relative rising landmass of northern Britain in the millennia during and since deglaciation. Each individual terrace represents a period of disruption to this long-term trend, when long-term incision was temporarily reversed. The recorded archaeology focuses on the Camphill and Maryculter Terraces (reflecting the focus of fieldwork to date, see 8.5 'Further work'), both essentially floodplains, but the existence of palaeochannels and other features permit the reconstruction of localised conditions that included drier, welldrained 'islands' suitable for settlement and other activity in prehistory, as well as wetter, less-favoured areas. Over time, as the river resumed its downward incision, each individual terrace surface would be abandoned above the lower, narrower watercourse, and a new terrace might be formed. They comprise riparian surfaces often favoured for activity by the communities who lived along the banks of the river.
The highest and oldest terrace, known as the Lochton Terrace, is made up of glaciofluvial sands and gravels that overlie the local till. They are representative of extensive outwash deposits laid down during the period immediately following the Last Glacial Maximum when melt and retreat was first initiated $c$ 18,000 years ago (Table 4.1). The surface of the Lochton Terrace lies between $17 \mathrm{~m}$ and $15.5 \mathrm{~m}$ above the present water surface at Nethermills. There are comparable gravels at higher altitudes, under Drumoak for instance, but these do not form terraces. This terrace thus represents almost the highest position of the river in this spot. In many places, infilled palaeochannels on the present Lochton Terrace surface attest to this earlier stage of the river when it occupied a series of braided channels that crossed the landscape immediately after deglaciation.

The second terrace surface, named the Maryfield Terrace, also comprises glaciofluvial sands and gravels similar to the Lochton Terrace. It lies between $11 \mathrm{~m}$ and $9.5 \mathrm{~m}$ above the present surface of the river at Nethermills and represents a lower stage of the river as it cut downwards. Stone tools of Late Upper Palaeolithic character have been found on this terrace at East Park (Illus 4.6). Assuming that they have not moved far, this suggests that 


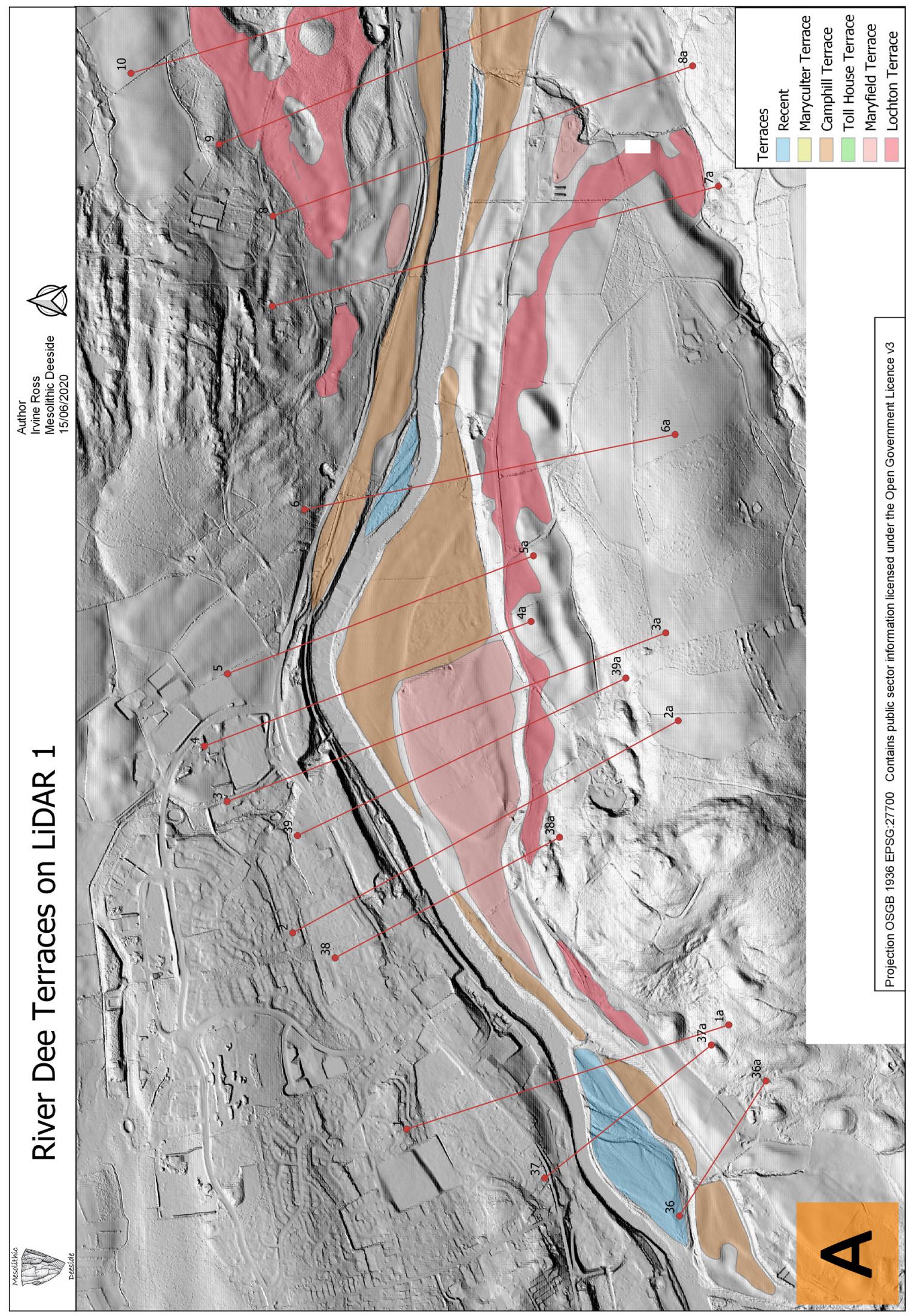

4
$\frac{1}{2}$
$\frac{1}{0}$

$\frac{\xi}{m} \frac{0}{\frac{8}{\sigma}}$

$\frac{n}{n}$

$\frac{\bar{\sigma}}{\sqrt{0}}$

흔

ब일

竞 $\frac{y}{\frac{1}{2}}$

ปั

气 ฮ̀

ธุ

茊

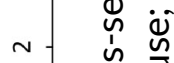

ஸิ 气

온 오

돈

ब

है 오

들

느을

त

$\stackrel{0}{ \pm}$

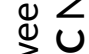

这

ำ

ฮิ

บั

产

ऐั

$\geq+$

뜬

论 产

กั

으 $m$

넝

인

ํํำ

옹

응

水产 


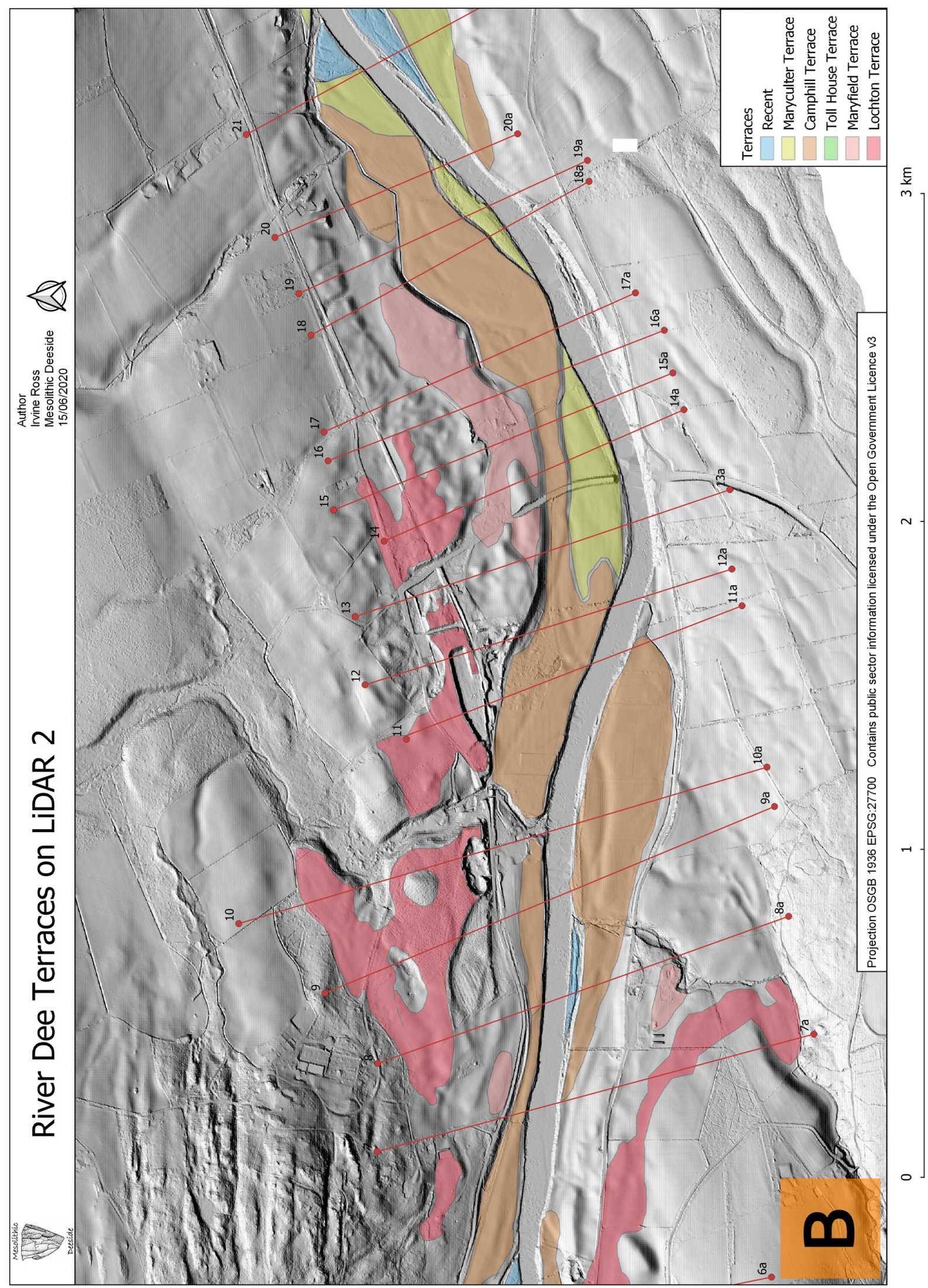




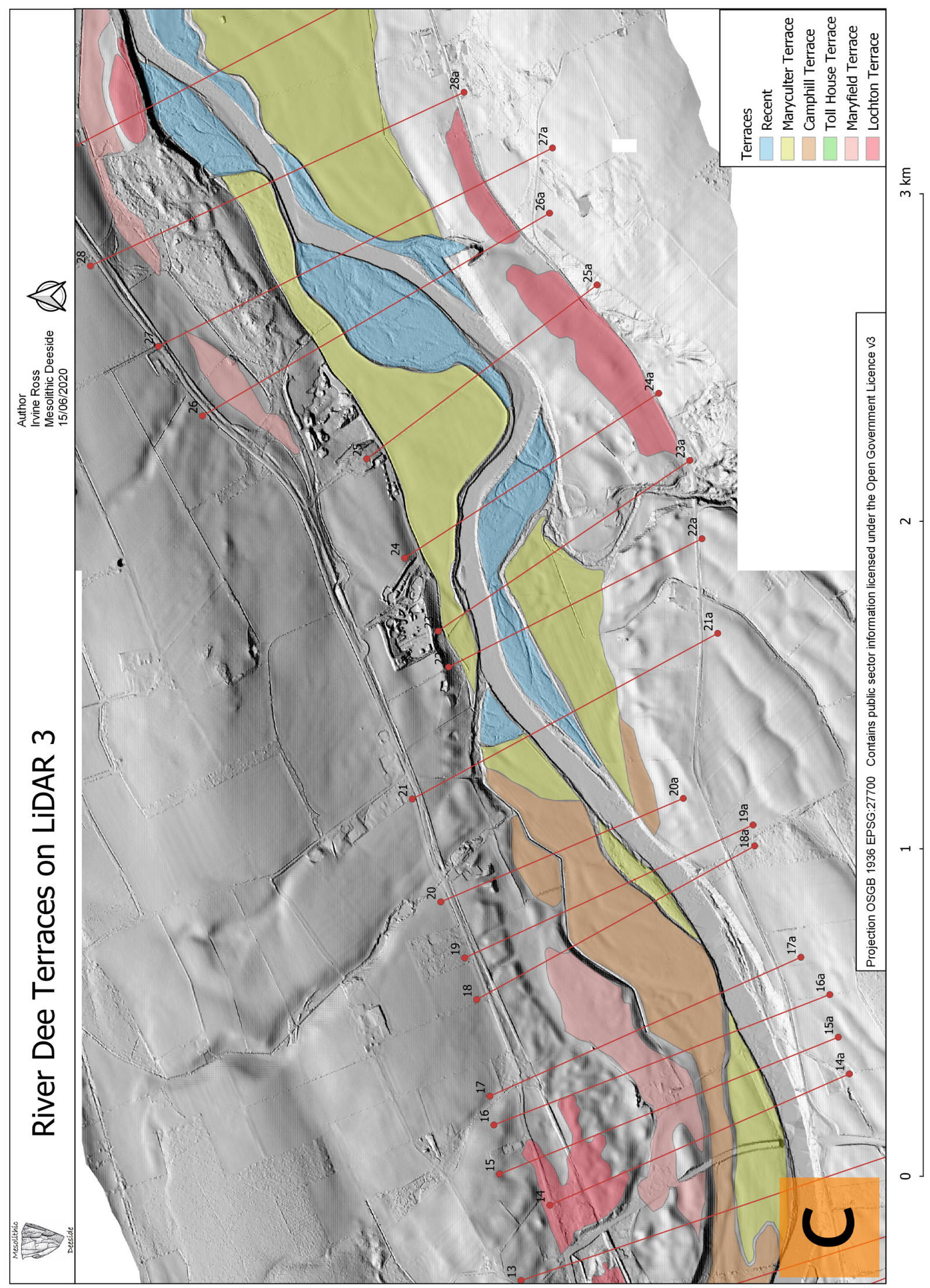




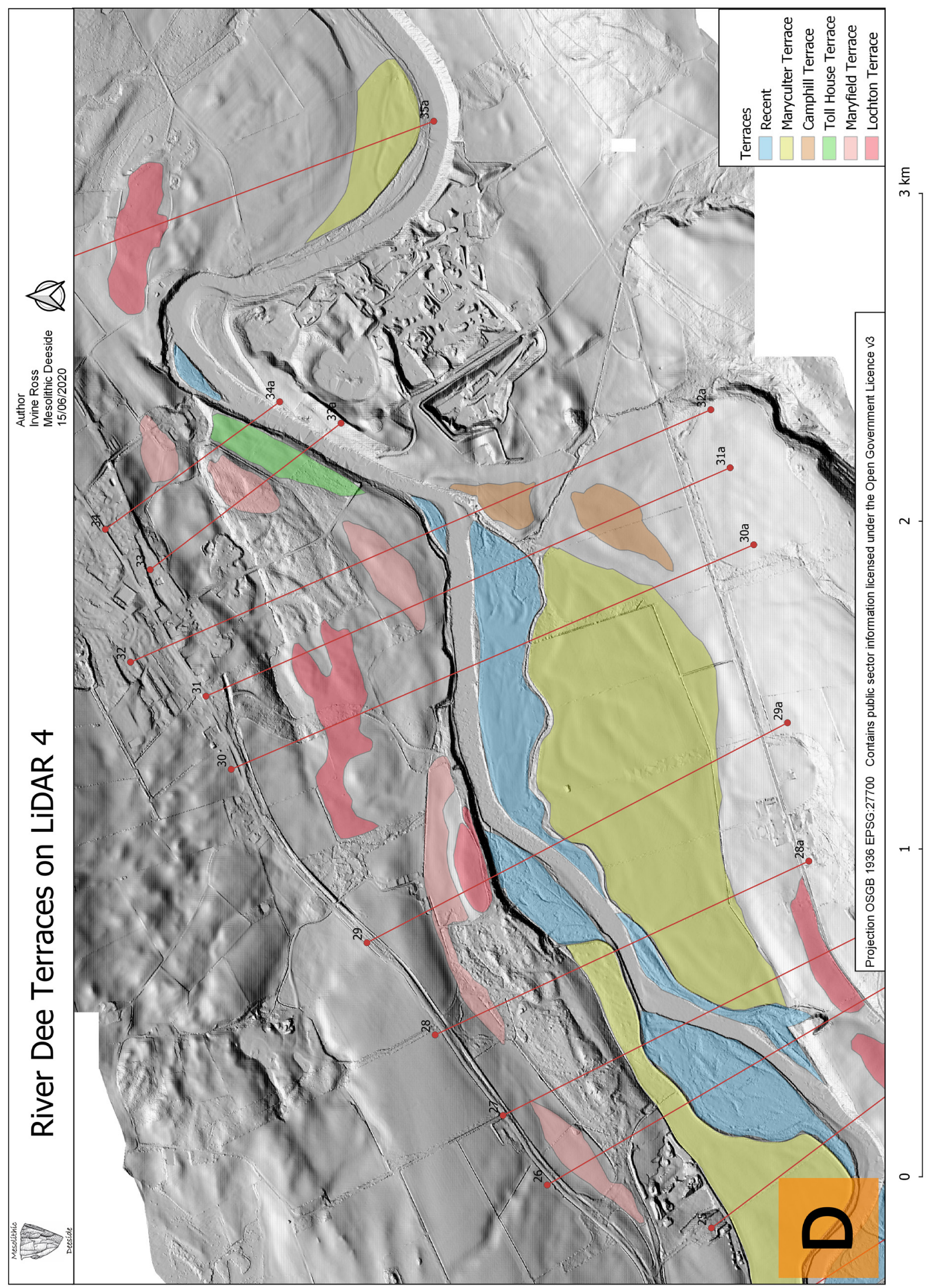




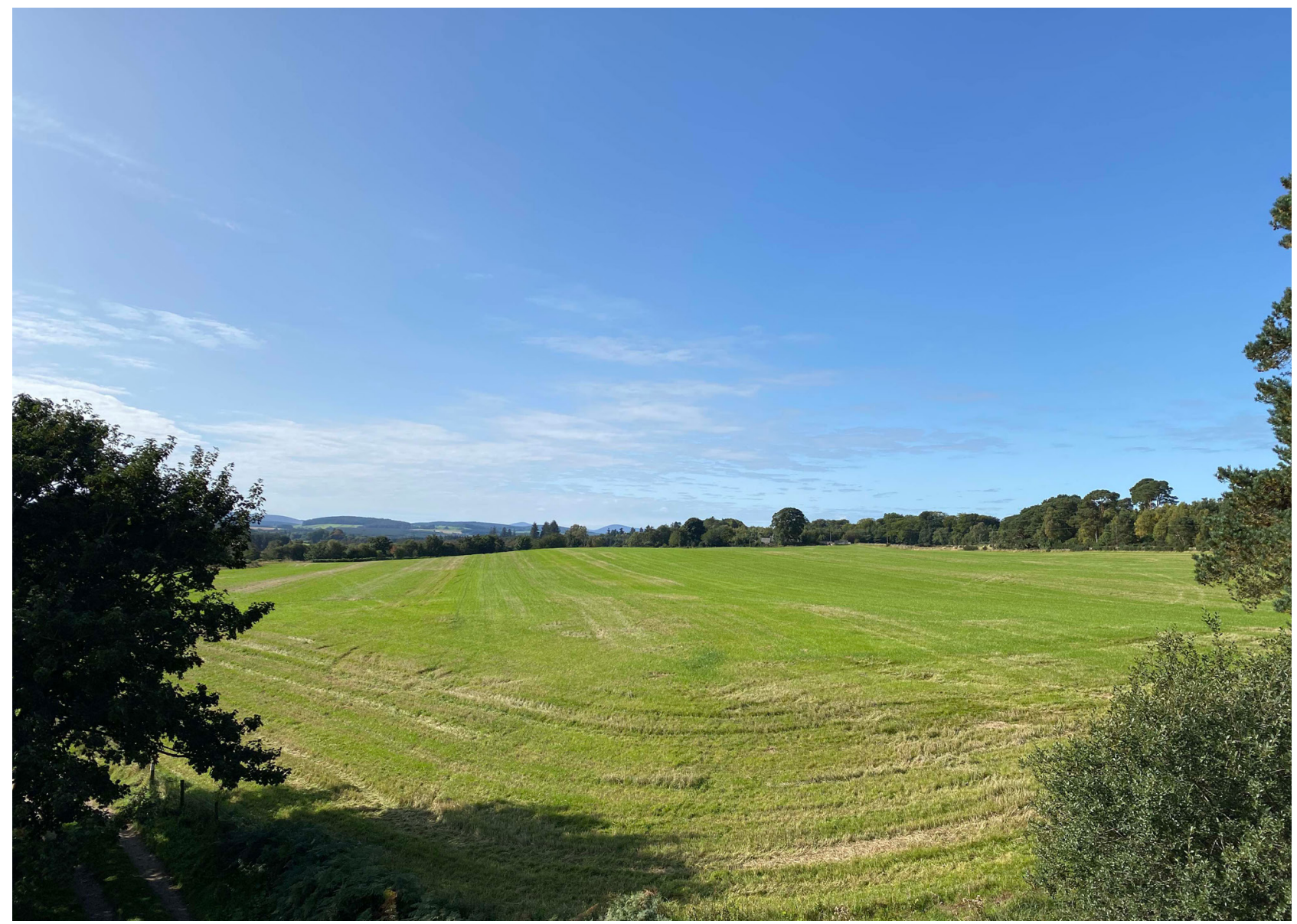

Illus 4.6 East Park; the higher, Maryfield, Terrace may be seen in the rear, dropping to the lower surface in the foreground

the terrace surface may have been in existence by c 13,000 cal BC. Below the Maryfield Terrace, some $6 \mathrm{~m}$ above the present surface of the Dee, a localised surface to the east of Park Bridge has been named the Toll House Terrace, but to date it has not been fieldwalked in detail.

The Camphill Terrace lies below the Maryfield Terrace along most of the Banchory-Dalmaik stretch of the river (Illus 4.7) and further downstream towards Milltimber and on into the City of Aberdeen. It sits around $4 \mathrm{~m}$ to $5 \mathrm{~m}$ above the present water surface and at Nethermills it has a gradient of around $1.9 \mathrm{~m}$ per kilometre. As the surface from which most archaeological material has been recovered to date, it is of particular importance. This terrace also comprises predominantly coarse gravels of the Lochton Formation, but at Nethermills they are overlain by thin sands that may be the product of fluvial activity during the Late Glacial Interstadial (c 12,700 вс to $c 10,900$ вс; Table 4.1) and the Younger Dryas ( $c 10,900 \mathrm{BC}$ to $c 9700 \mathrm{BC}$ ). Fossilised palaeochannels may be observed on the terrace surface, and the evidence suggests that these began to fill with peat in the earliest Holocene $c 9700 \mathrm{cal} \mathrm{BC}$ (Ewan 1981; Tipping 2007). The Dee may, thus, have incised below the terrace before the Holocene. At both Nethermills Farm and Milltimber a possible terminus post quem for the formation of the terrace is suggested by finds of Late Upper Palaeolithic stone tools recovered from the surface deposits. Assuming these to represent activity in the area, they would indicate that the terrace surface had formed by c 13,000 cal вс. At Milltimber, an assemblage of Mesolithic lithics located towards the uphill side of this terrace seemingly avoided the main terrace surface, suggesting to the excavators that the terrace here may have comprised the active floodplain at the time of Mesolithic activity and may have been too wet for occupation. At Nethermills Farm, upstream of Milltimber, Mesolithic finds are scattered across the surface of the Camphill Terrace, though they avoid the palaeochannels to either side (Illus 4.8), 


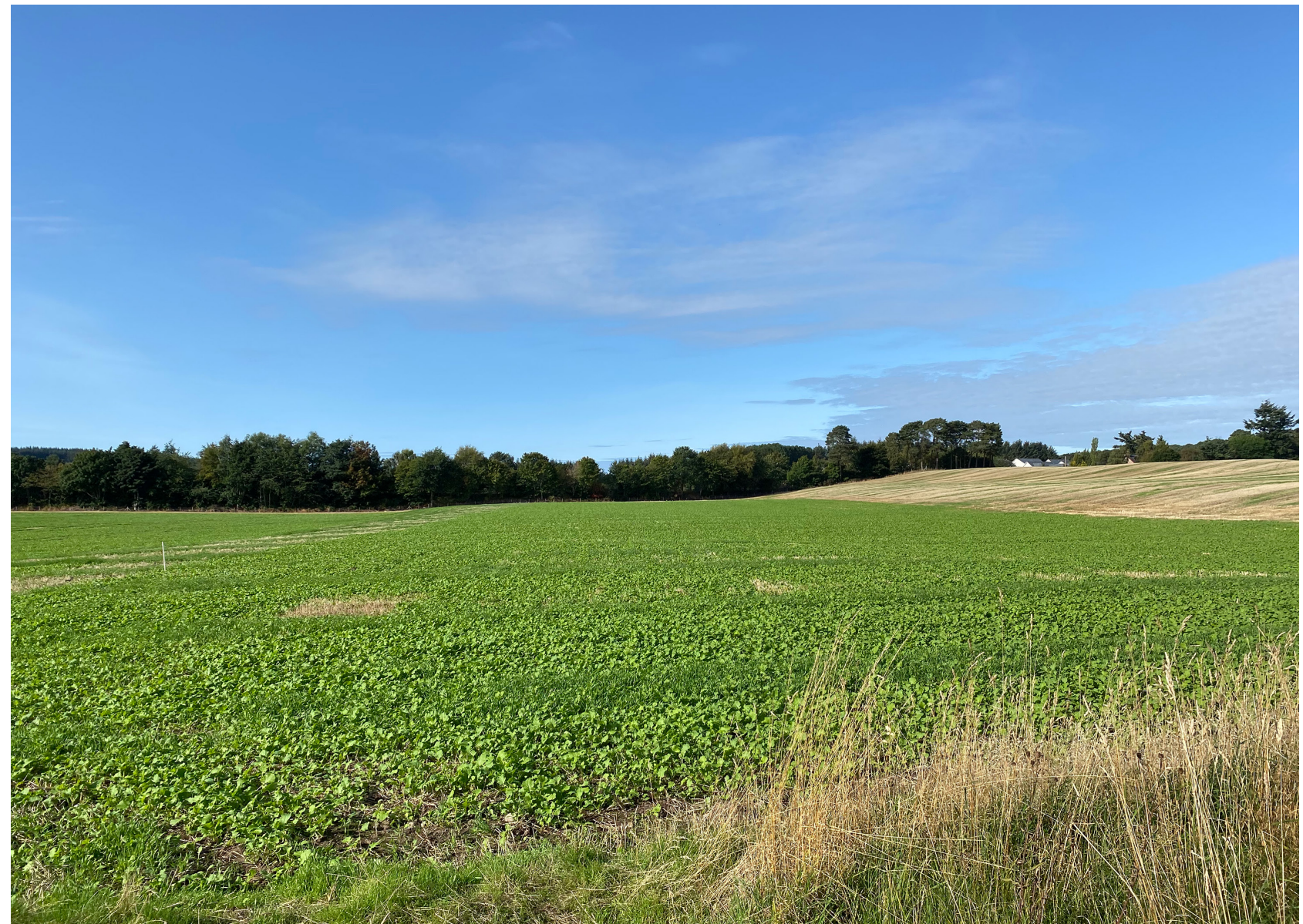

Illus 4.7 Nethermills Farm NM2, showing three terrace surfaces: the higher Maryfield Terrace in stubble to the right of the photograph, dropping to the Camphill Terrace in the centre, and on down to the lower Maryculter Terrace towards the left

suggesting that by the late 6 th millennium $\mathrm{BC}$ the terrace here included better-drained, drier 'islands' upon which human activity was focused, as well as waterlogged palaeochannels. The evidence suggests that the river here had ceased to be a braided river system before the Late Upper Palaeolithic lithics were deposited and is likely to have occupied a couple of broad shallow channels.

Lower still, the youngest terrace is largely composed of sand with some alluvium and is known as the Maryculter Terrace. At Nethermills it lies between $2 \mathrm{~m}$ and $3 \mathrm{~m}$ above the present river surface, with a gradient of $1.9 \mathrm{~m}$ per kilometre. In places it rises close to the height of the Camphill Terrace, as at Durris Bridge. The sand of the Maryculter Terrace is the product of floods periodically spreading lighter particles across the floodplain while the heavier gravel remains trapped in the channel itself. OSL dating of the uppermost $1.75 \mathrm{~m}$ of sand in the Maryculter Terrace at Milltimber indicates that these accumulated from $c 2500 \mathrm{cal}$ вС (Tipping \& Kinnaird 2019), suggesting a date by which time terrace formation must have been underway. This is supported by the presence of Neolithic buildings across the Camphill Terrace, above this surface, at Milltimber, dated to between 2470 and 2205 cal вC (Dingwall et al 2019b). These are thought to suggest the drainage and drying of that terrace (thus inviting human settlement), as the river incised downwards to form the lower Maryculter Terrace.

While the static framework of terracing presented here provides a sound geomorphological context for the archaeological finds today, these descriptions can appear to mask the essential dynamism of the world experienced by the communities of early prehistory. Changes such as the downward incision of the river might not have been obvious to people within a single generation, but the experience of living within a landscape subject to dramatic change is likely to have been preserved in collective memory. Events 


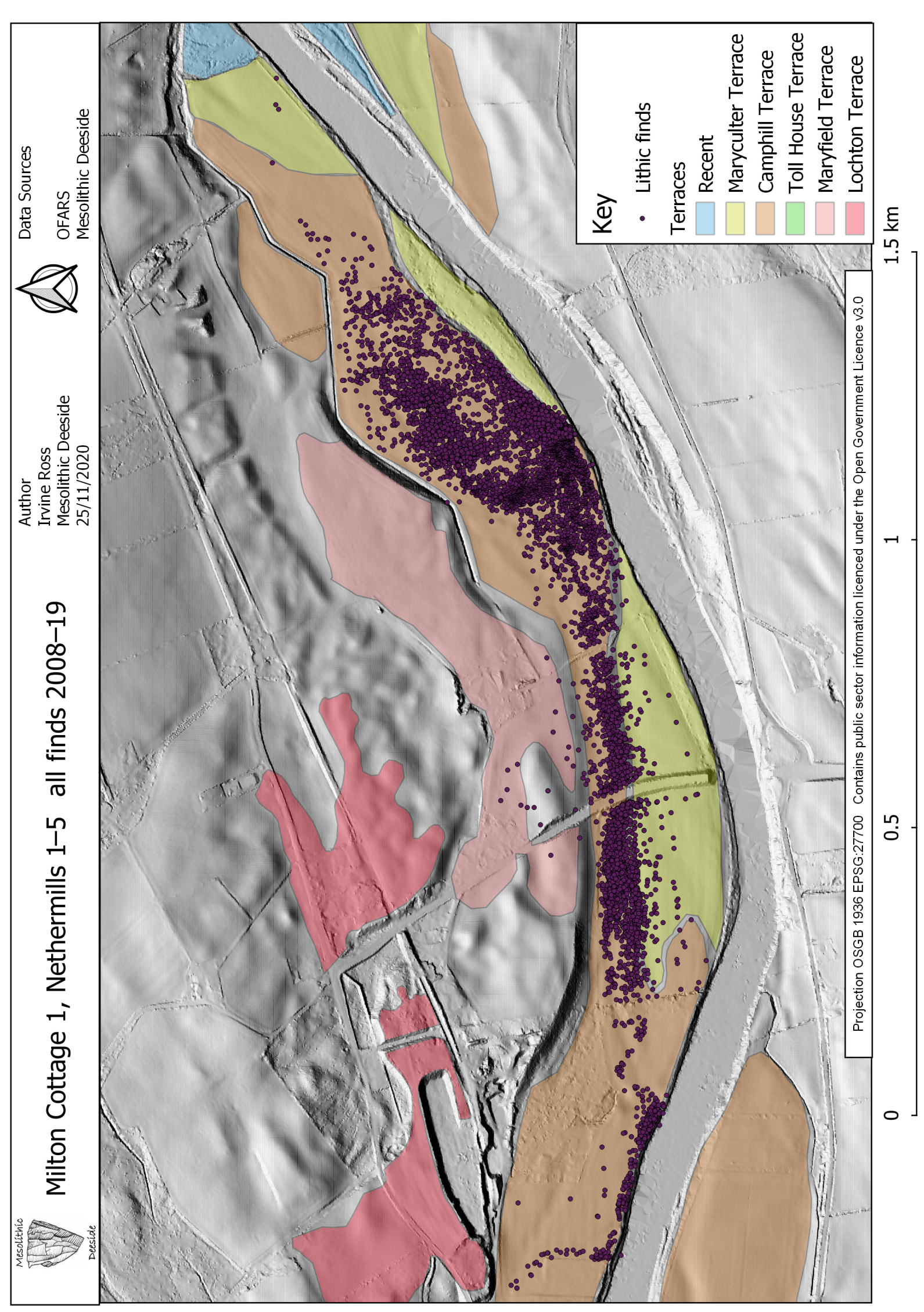

芩

$\stackrel{1}{\sim} \stackrel{0}{\mp}$

$\sum . \frac{0}{0}$

ह

$\stackrel{4}{\longleftarrow}$

$\cong$

$\varepsilon$ त

ญ ऐ

乙望 $\sum_{0}^{\infty}$

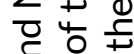

के

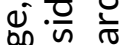

更㐫

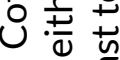

ㅇำ

产 $\frac{n}{0} \frac{1}{ \pm}$

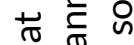

는 $\frac{5}{5}$

ब

능 응

는흔

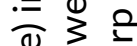

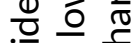

可

$凶=\frac{\pi}{0}$

능

至

:

$\sum^{0} \frac{1}{\frac{1}{U}}$

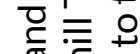

๗ิํํ늠

政

峲怘

0 임

국

구은 는

잉 즌 든

눰

जั

战

$\overline{\bar{\sigma}} \simeq$

㑔 음

드 은 흔 음

式 讨

든 응

.동

㝴

F

我 는.

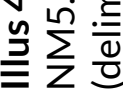


such as flash floods or unusually dry summers will also have been enshrined within local stories and histories. Through both time and space, the River Dee provided a variety of ecozones that facilitated human settlement along its course. As the river course developed and migrated downwards, so the local landscape oscillated between open-to-woodland and poorly drained-to-dry, with concomitant changes in climate. This was a dynamic world that brought both opportunity and challenge to those who lived in it; it was a world in which local communities had to be both flexible and resilient.

\subsection{Climate, vegetation and landscape}

The inclusion of material indicative of Late Upper Palaeolithic activity from several of the fieldwalked sites necessitates consideration of the landscape and environment back to the period of deglaciation (Table 4.1).

Throughout the period of human activity, the detail of the land has changed. One driving factor has been the dynamic nature of relative sea-level, itself a result of a combination of elements, in particular isostatic and eustatic movement (Dawson 2018; Wickham-Jones 2018), meaning that the position of the coast has altered. Sea-level models are still being refined but the most recent data (Illus 4.9) suggest that relative sea-level around Aberdeen may have been much higher at the end of the Last Glacial Maximum. It subsequently fell abruptly to a local low after 11,000 вс before rising again, so that by around 8000 BC relative sea-level lay about $9 \mathrm{~m}$ below present, adding a distance of around 1 kilometre to the available land (give or take the precise coastal topography). It then rose to current OSL around $6000 \mathrm{BC}$, reaching some $3.5 \mathrm{~m}$ above present around $5000 \mathrm{BC}$, before undergoing a series of fluctuations to attain present height (Sarah Boyd, pers comm; Smith et al 1999; Shennan et al 2018). When people first arrived in the area during the 13th millennium $\mathrm{BC}$, though the coastal plain is likely to have extended slightly to the east, Doggerland, while still in existence, lay several hundred kilometres to the south-east (Sturt et al 2013). The Dee flowed into an extensive bay: a 'North Sea Bight', bordered by the coasts of the British Isles to the west and Doggerland which lay far to the south-east. Throughout the history of human activity in the area, the local details of land and sea have changed, though the overall position
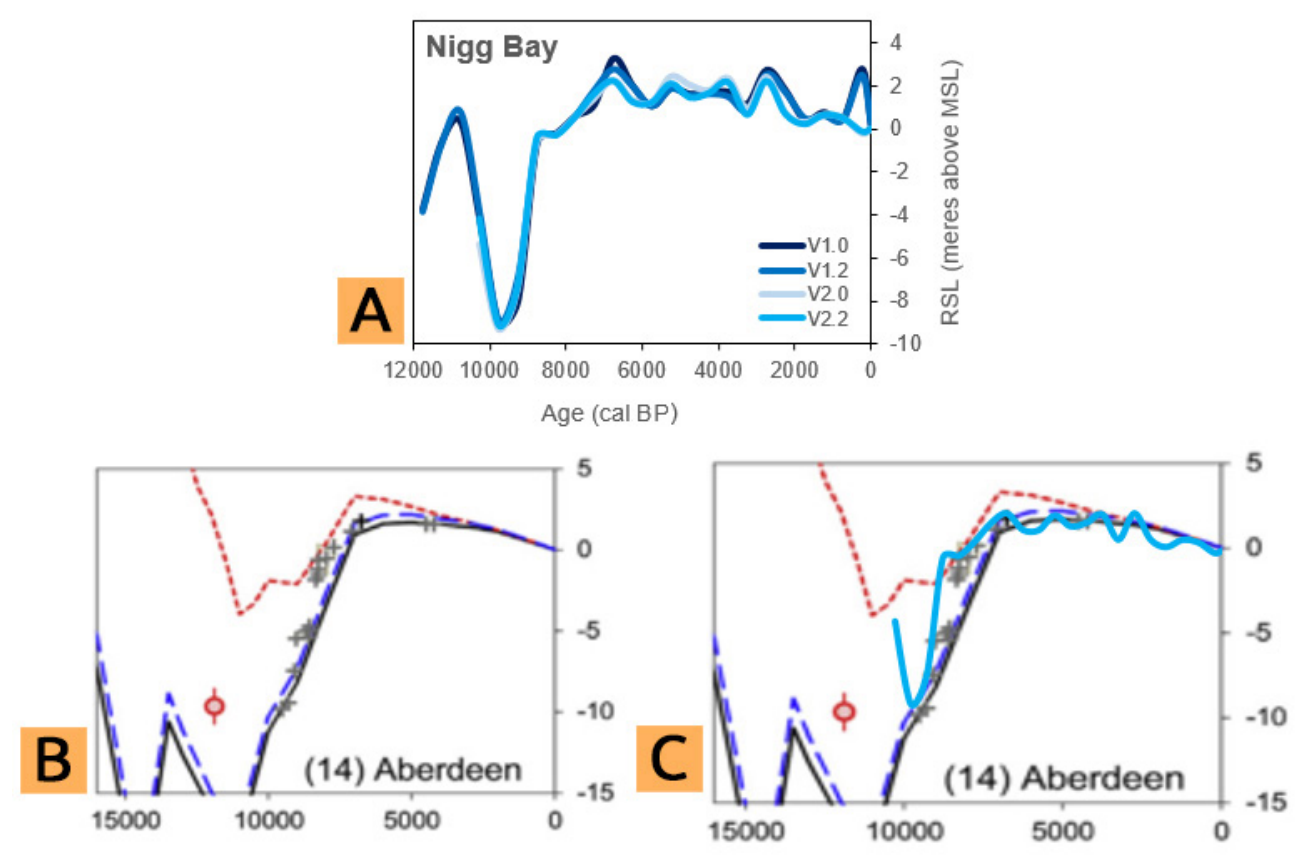

Illus 4.9 Relative sea-level curve for the coast at Aberdeen. A Sarah Boyd, pers comm; B Shennan et al (2018); C Boyd overlain on to Shennan et al (2018), indicating a general correspondence, but highlighting a number of small fluctuations throughout the Holocene 
of the communities here, bordering the river as it ran to the sea, remained constant.

During the peak of the last glaciation, 31,000 вС to 18,000 вC, the Scottish ice sheet along the Dee extended east of Aberdeen (Ballantyne \& Small 2019). Bedrock is usually plastered with glacial till, generally known as the Banchory Till Formation (Merritt et al 2003). Deglaciation was, in detail, complex, the area of the present-day coast being initially exposed around 14,500 $\mathrm{BC}$, and interrupted by periods when ice-fronts slowed, halted or re-advanced (Brown 1993; Merritt et al 2003; Hall et al 2016; Ballantyne \& Small 2019). In general, it is poorly dated along Deeside.

Deglaciation of the Dee catchment is thought to have been complete by the onset of the first clear climatic amelioration $c 12,750 \mathrm{BC}$ (Ballantyne \& Small 2019), known as the Late Glacial or Windermere Interstadial (Lowe et al 2008; Walker \& Lowe 2019). Locally, the Loch of Park warmed sufficiently to encourage the formation of organic lake muds (gytta). Analysis of beetle remains in lake muds at Abernethy on Speyside suggests that mean summer temperatures rose to more than $13^{\circ} \mathrm{C}$ by $12,000 \mathrm{BC}$ (Brooks et al 2012). The hills and valleys of lower Deeside were open landscapes. Bedrock all along Deeside gives rise to acid soils. These features supported heathland dominated by crowberry (Empetrum), a plant that out-competes most others on very dry soils, conditions probably induced by high winds, low precipitation and strong summer evaporation (Birks \& Birks 2014). Woodland was rare in eastern Deeside throughout the Late Glacial Interstadial despite the warmer temperatures. The evidence indicates that it was limited to birch (Betula), willow (Salix) and juniper (Juniperus), the first two perhaps largely confined around lakes, though birch may have been more common further inland (Vasari \& Vasari 1968). Suppression of tree seedlings by herbivores is possible (van Asch \& Hoek 2012; Bakker et al 2016; Ballin et al 2018), though currently speculative. Large lakes created during deglaciation were still common. Many deep meltwater channels cut during deglaciation were quite fresh. These and smaller watercourses facilitated both movement through the landscape and settlement, in addition to presenting opportunities for the gathering of resources. When people colonised the area the active floodplain, the
Camphill Terrace, had already been formed, some $15 \mathrm{~m}$ below the oldest river terraces. It occupied a valley floor that was, in places, several hundred metres wide (eg at Heughhead). This floor comprised an uneven gravel surface of lozenge-shaped gravel bars surrounded by shallow palaeochannels, most of which would have been dry until winter. The Late Glacial Interstadial $(12,700 \mathrm{BC}$ to $10,900 \mathrm{BC})$ is the time interval that Ballin (2019) considered most likely to have seen human activities at Milltimber.

The later part of the Late Glacial Interstadial, c 12,000 to $c 10,700 \mathrm{BC}$, was slightly cooler, probably wetter, and less windy (Birks $\&$ Birks 2014). Woodland remained scarce in eastern Deeside. Temperatures fell rapidly with the advent of the Younger Dryas ( $c 10,900 \mathrm{BC}$ to $c 9700 \mathrm{BC})$ with abrupt falls in mean summer temperatures by at least $7^{\circ} \mathrm{C}$ (Brooks et al 2012), and a possible further drop in winter by around $20-22^{\circ} \mathrm{C}$ (Denton et al 2005). Glacial conditions returned in the Cairngorm massif in the form of localised valley and corrie glaciers (Golledge 2010; Bickerdike et al 2018). The climate in eastern Scotland again became more arid as precipitation gradients from west to east steepened (Benn \& Ballantyne 2005). There is currently no sedimentological evidence along mid and lower Deeside for accelerated Younger Dryas fluvial activity. Terrestrial plant communities were decimated, leaving an Artemisia steppe. The extent of bare ground favoured soil erosion, particularly over seasonally frozen ground (Connell \& Hall 1987) and this was washed into lakes where organic productivity had collapsed (Walker \& Lowe 2019). The climatic impact on the human communities here would have been considerable; there is, to date, only one Scottish archaeological site, on Islay, where occupation in the latter part of the Younger Dryas is suggested (Mithen et al 2015).

Rapid warming at the onset of the Holocene (Brooks et al 2012) suddenly changed the landscape of eastern Scotland. Mean summer temperatures at Abernethy rose during the latter part of the Younger Dryas, after $c 10,100 \mathrm{BC}$, to around $10^{\circ} \mathrm{C}$ (Brooks et al 2012), and there was a further rise to around $14^{\circ} \mathrm{C}$ at $c 9700 \mathrm{BC}$ (Lowe et al 2008). Precipitation increased, soils stabilised, organic matter in soils and in lakes increased, bare ground was reduced. Empetrum and Juniperus re-established on rapidly maturing terrestrial soils before the immigration 
of Betula around 9600 вс, hazel (Corylus) between 8500 and 8000 вс, oak (Quercus) and elm (Ulmus) after 7725-7595 вС (Tipping 2007: 33; Dingwall et al 2019b: 33). Scots pine (Pinus sylvestris) pushed east for a short while after $c 5800 \mathrm{BC}$, from the Cairngorms to Loch Davan (Edwards 1978) and Loch Kinord (Vasari \& Vasari 1968). In the Cairngorms, birch charcoal from the site at Chest of Dee has been dated to the late 9th millennium вС (8290-7990 вс, SUERC-58528, 8977 \pm 29$)$, with Scots pine, and some willow (Salix), from the 8th millennium (for example: 7050-6770; SUERC58527, 7990 28; Wickham-Jones et al 2020), while at Caochanan Ruadha yew (Taxus) and alder (Alnus) have recorded late 7 th-millennium $\mathrm{BC}$ dates (for example: 6210-6050 вс, SUERC-58040, 7252; 6200-6010 вс, SUERC-67814, 7210; Warren et al 2018). Along lower Deeside, plant communities may have been disturbed by short-lived but intense, cold and dry climatic fluctuations around 7300 BC (Hoek \& Bos 2007; Lang et al 2010), 6200 вС (Alley et al 1997; Seppä et al 2007) and 4200 вС (Karlen \& Larsson 2007; Tipping 2010).

By the time of Mesolithic settlement in the early 8th millennium BC, therefore, local deciduous woodland had altered the landscape of the lower Dee Valley (Illus 4.10), in contrast with the evidence for pine forests higher into the Cairngorms (Paterson 2011; Wickham-Jones et al 2020). Open canopy birch and hazel woodland was recorded during the excavation of an early 8th-millennium BC site at Warren Field, Crathes (Davies et al 2009; Tipping in Dingwall et al 2019b: 30-7). Ewan's (1981) pollen analyses from Nethermills Farm recorded the local development of birch, hazel and oak, together with alder and willow, growing on a reasonably dry terrace surface above the contemporary river. Open ground habitats may have diminished from c $7500 \mathrm{BC}$ but where the tree cover thinned there is evidence for grasses and herbs, including Filipendula (meadowsweet), Potentilla (tormentil), and other Rosaceae. The woodland at Nethermills Farm provided resources, whether to serve structural needs (Boyd \& Kenworthy 1992 discuss the selection of oak), or as food (carbonised hazelnut shells were plentiful on Kenworthy's excavation: Boyd \& Kenworthy 1992; Wickham-Jones et al 2017). Tipping discusses the subsequent loss of oak from the valley floor and increase in birch with some return to a more open, grassy habitat (Dingwall et al 2019b: 35-7). This took place some time in the later 6th millennium BC. These changes need not have been anthropogenic: edaphic or climatically driven fluctuations in plant communities are alternative explanations (Tipping 2004). Little pollenanalytical evidence for hunter-gatherer disturbance of woodland in lower Deeside has survived criticism (Edwards \& Ralston 1984; Tipping 2007: 38-9).

Though deciduous woodland probably blanketed terrestrial soils, the canopy was not necessarily closed (Fyfe et al 2013). Tipping presents a vivid picture of walking through this Early Holocene woodland (in Dingwall et al 2019b: 35-7): while the canopy was varied and included open vistas and clearings, dense undergrowth could impede movement in places. Movement for people and large animals would have been easier along the watercourses.

Around this time existing lakes began to infill with fens. Peat bogs formed in basins and abandoned glacial meltwater channels from between $c 8500$ and 7500 вс (Clark \& Edwards 2004; Tipping 2007: 34). Reduced sediment loads led to rivers becoming single-channel meandering systems or sluggish, multi-channelled anastomosing systems on valley floors that were probably much wetter than today; colonised by birch, willow and, after $c 5750 \mathrm{BC}$ in the Dee lowlands, alder (Alnus) (Tipping 2007: 38).

We understand very little of the fluvial dynamics of the Dee in this period, but the Camphill Terrace is likely to have continued as the active floodplain at this time. Nevertheless, contrasting impressions of this surface along the course of the river are apparent. Reconsideration of information from excavation undertaken by Paterson \& Lacaille (1936) suggests that at Birkwood the terrace surface was actively built up by the accumulation of flood sediment within the Mesolithic, though modern investigation has yet to take place. At Potarch and Balbridie the lithic scatters seem to avoid peat-filled channels, suggesting that they may represent active river channels in the Mesolithic. A similar situation occurs at Nethermills Farm, only $5 \mathrm{~km}$ downstream, where the lithics occupy slightly higher ground between two palaeochannels. The evidence suggests that the Camphill Terrace here was dry and wooded for much of the Mesolithic, though water flow through the palaeochannels in time of flood may itself have accentuated the archaeological patterning 

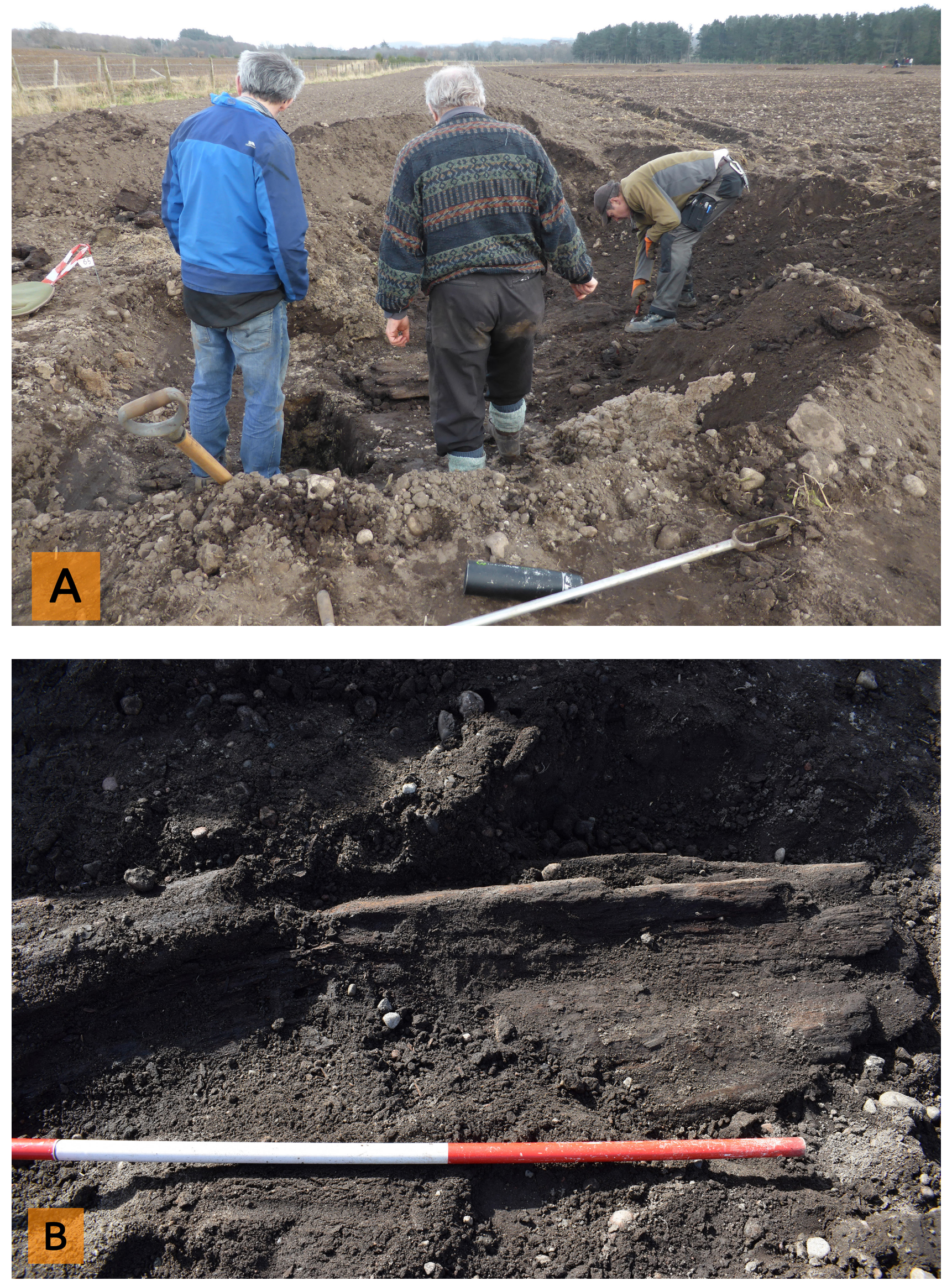

Illus 4.10 A Investigation of preserved tree remains in the northern palaeochannel at Nethermills Farm NM4 in 2019; B Detail of the preserved timber 
by dominantly moving material from immediate bankside locations. Further east at Milltimber change can only be inferred from the archaeological record, as Early Holocene fluvial sediment, if it existed, was removed by industrial stripping before it could be examined. The concentration of archaeology here lies at the back of the terrace and has been used to argue that the terrace surface may have been wetter and less conducive to settlement towards the river (Dingwall et al 2019b).

By the beginning of the 4th millennium BC, farming had been established in Scotland. The local history of woodland cover along the river in this period was varied. The significance of the Dee Valley as a corridor that facilitated both agriculture and movement among the early farmers of the time has been noted by many (eg Murray et al 2009; Dingwall et al 2019b). Terrace surfaces like the Camphill Terrace, dry or drier by this time and with fertile, newly developed soils formed from Holocene alluvium, were highly suitable for the requirements of the pioneering farming communities as they moved up the river. The earliest Neolithic settlement recorded in the area to date, $c 3800$ BC at Warren Field, Crathes, was in a cleared opening in a woodland locally dominated by Corylus (Davies et al 2009; Tipping et al 2009).
Radiocarbon dating at Nethermills Farm makes it likely that the transformation of local woodland here occurred around $4100 \mathrm{BC}$ and included the total loss of willow, the collapse of the local oak population, and expansion to local dominance of Betula, grasses, and the grazing indicator, ribwort plantain (Plantago lanceolata) (Ewan 1981; Wickham-Jones et al 2017). At Braeroddach Loch in the Howe of Cromar, the first Plantago lanceolata pollen grains are radiocarbon dated, and calibrated to 4551-3782 cal BC, though in general the woodland remained little disturbed (Edwards 1979). Around the Loch of Park, and nearby at the Red Moss of Candiglarich, near Drumoak, woodland was barely disturbed in the Early Neolithic (Vasari \& Vasari 1968; Clark \& Edwards 2004). With regard to the crops themselves, and at a smaller spatial scale, settlement at Warren Field, albeit short-lived, was accompanied by crop-growing immediately around the timber hall (Davies et al 2009; Tipping et al 2009), with plant macrofossil evidence for Triticum vulgare (bread/club wheat) and Hordeum vulgare (naked barley) (Hastie, Timpany in Lancaster 2009). Cropgrowing was a major land use at nearby Balbridie (Fairweather \& Ralston 1993) and at Garthdee Road, Aberdeen (Timpany 2014). 